\title{
THE TUNIC OF CHRIST AND THE CROWN JEWELS: RELICS IN THE BYZANTINE DIPLOMACY OF THE FOURTEENTH CENTURY
}

\author{
Tatiana V. Kushch \\ Ural Federal University, Yekaterinburg, Russian Federation; \\ Institute of World History of the Russian Academy of Sciences, Moscow, Russian Federation
}

\begin{abstract}
Introduction. This article discusses the "reliquary diplomacy" introduced by Emperor Manuel II Palaiologos during the Ottoman siege of Constantinople (1394-1402). The emperor widely used the relics in the creation of the anti-Ottoman alliance. This article addresses a specific case of this diplomatic practice, Manuel II Palaiologos' request to Venice for a loan for the deposit on the Tunic of Christ and other relics. Methods. From the juxtaposition of sources and the comparative analysis of the fourteenth-century relations between Byzantium and Venice there are good reasons to discover the motives behind the Venetians' denial of the emperors' proposal. Analysis. After 1261 Constantinople kept numerous relics, particularly the Seamless Tunic of Christ and the Purple Robe. The sources in possession do not allow an unequivocal conclusion if the artifact offered to the Venetians was the Seamless Tunic or another one. In the author's interpretation, the reason of Venice's withdrawal from the deal was the empire's bad "credit history." In August 1343, the Senate of Venice gave credit of 30,000 gold ducats to the Empress Anna of Savoy for the deposit of the jewels of the crown. The Venetians permanently reminded Byzantium about the repayment of the debt and the ransom for the jewels, and, moreover, offered to take the island of Tenedos as a compensation. Therefore, the unsolved problem of the old debt made the new deal with the emperor hopeless in the Venetians' eyes. Results. The case under analysis sheds light on the state of the Empire in the late fourteenth century. Manuel II Palaiologos put into the "diplomatic circulation" the relics which were convertible in the Christian West. The failure of his negotiations with Venice turned him to active search for other allies, whom he sent parts of the Tunic of Christ in order to gain their military and financial support.
\end{abstract}

Key words: Late Byzantium, Venice, Manuel II Palaiologos, relics, reliquary diplomacy.

Citation. Kushch T.V. The Tunic of Christ and the Crown Jewels: Relics in the Byzantine Diplomacy of the Fourteenth Century. Vestnik Volgogradskogo gosudarstvennogo universiteta. Seriya 4. Istoriya. Regionovedenie. Mezhdunarodnye otnosheniya [Science Journal of Volgograd State University. History. Area Studies. International Relations], 2021, vol. 26, no. 6, pp. 161-170. (in Russian). DOI: https://doi.org/10.15688/jvolsu4.2021.6.14

УДК 94“13”:27-526.7

Дата поступления статьи: 07.06.2021

ББК 63.3(0)4-93 Дата принятия статьи: 25.10.2021

\section{ТУНИКА ХРИСТА И ДРАГОЦЕННОСТИ КОРОНЫ: РЕЛИКВИИ В ВИЗАНТИЙСКОЙ ДИПЛОМАТИИ XIV ВЕКА}

\author{
Татьяна Викторовна Кущ \\ Уральский федеральный университет, г. Екатеринбург, Российская Федерация; \\ Институт всеобщей истории РАН, г. Москва, Российская Федерация
}

\footnotetext{
Аннотация. Статья посвящена изучению «реликварной дипломатии» византийского императора Мануила II Палеолога в условиях османской осады Константинополя (1394-1402). Император широко использовал святые реликвии для создания антитурецкого союза. В статье рассматривается один из примеров त подобной дипломатической практики - просьба Мануила Палеолога о предоставлении Венецией займа под э. залог туники Христа и других реликвий. Сопоставление источников и анализ отношений Византии и Венеции в XIV в. позволяют выявить мотивы отказа венецианцев от предложения императора. Отмечается, что в Константинополе после 1261 г. хранились многие реликвии, среди которых были нешвенная туника и багря(?) ница Христа. Источники не позволяют сделать однозначный вывод, была ли предложенная венецианцам
} 


\section{ВИЗАНТИЙСКОЕ ОБЩЕСТВО И ГОСУДАРСТВО}

туника идентична нешвенной тунике или речь шла о какой-то другой тунике. Причина же отказа Венеции от сделки крылась, по мнению автора статьи, в плохой «кредитной истории» империи. В августе 1343 г. венецианский Сенат выделил императрице Анне Савойской заем в размере 30 тыс. золотых дукатов под залог драгоценностей императорской короны. О возврате долга и выкупе драгоценностей венецианцы постоянно напоминали Византии и даже предлагали передать их в качестве компенсации за о. Тенедос. Нерешенная проблема старого долга делала в глазах венецианцев новую сделку с императором безнадежной. Рассмотренный случай иллюстрирует состояние империи в конце XIV века. Мануил II Палеолог пустил в «дипломатический оборот» те реликвии, которые конвертировались на христианском Западе. Неудача на переговорах с Венецией вынудила его активнее искать других союзников, которым он раздавал по частям тунику Христа, рассчитывая на их военную и финансовую помощь.

Ключевые слова: Поздняя Византия, Венеция, Мануил II Палеолог, реликвии, реликварная дипломатия.

Цитирование. Кущ Т. В. Туника Христа и драгоценности короны: реликвии в византийской дипломатии XIV века // Вестник Волгоградского государственного университета. Серия 4, История. Регионоведение. Международные отношения. - 2021. - Т. 26, № 6. - C. 161-170. - DOI: https://doi.org/10.15688/jvolsu4.2021.6.14

Введение. Весной 1394 г. турки осадили Константинополь ${ }^{1}$. Это был серьезный вызов Византийской империи, чьи владения к тому времени ограничивались землями вокруг Константинополя, несколькими эгейскими островами и Морейским деспотатом на Пелопоннесе. Осада обещала быть долгой - турки блокировали город только с суши, время от времени пытаясь атаковать его крепостные стены [9, р. 128]. И хотя турецкие суда курсировали в прибрежных водах, константинопольцы сохраняли по морю связь с внешним миром и могли получать помощь извне. Ситуация вынуждала византийского императора Мануила II Палеолога (1391-1425) к решительным действиям. Прежде всего нужно было позаботиться об обеспечении продовольствием населения осажденного города: отрезанное от сельскохозяйственной округи, оно нуждалось в поставках хлеба и других товаров первой необходимости.

Еще более масштабная проблема, которую предстояло решать императору, - это поиск финансовой и военной поддержки извне, без которой Константинополь бы не смог долго продержаться. В ход пошла дипломатия, с помощью которой империя пыталась создать антиосманский альянс или, по крайней мере, добиться финансового и военного участия европейских правителей в борьбе с турками. Очевиден был и выбор потенциального союзника - это, прежде всего, Венеция, с которой империю связывали тесные, прежде всего, экономические отношения и которая сама была кровно заинтересована в стабильности восточно-средиземноморского региона.
К Республике Св. Марка византийцы в первую очередь и обратились за помощью. Уже 21 мая 1394 г. ее Совет, обсуждая дела на Востоке, поручил своим резидентам в Константинополе выразить Мануилу слова поддержки, убедить его не покидать город, чтобы не усугубить ситуацию, а также рекомендовать ему обратиться к папе римскому, императору Германии, правителям Франции и Англии с просьбой о помощи. Республика заявила о своей готовности выступить посредником и доставить письма указанным адресатам [29, № 851; 9, p. 124]. Очевидно, Венеция уклонялась от оказания реальной помощи империи, ограничиваясь выражением беспокойства и общими заявлениями о поддержке. Спустя два месяца, 24 июля 1394 г., Сенат, отвечая на очередное обращение Мануила II Палеолога, призвал его не терять мужества и заверил, что в случае ухудшения ситуации в византийской столице Республика предоставит императору галеры для бегства в Венецию или на о. Лемнос [29, № 860]. Лишь в конце 1394 г. (23 декабря), когда даже венецианцы признали, что положение в осажденном Константинополе стало крайне тяжелым, Сенат известил византийского посла об отправке 1,5 тыс. модиев пшеницы, о чем так давно и настоятельно просил император. Однако на просьбу войти в антитурецкую коалицию республика отреагировала уклончиво, сославшись на отсутствие в данный момент послов, которые могли бы обсуждать этот вопрос [29, № 871]. Только спустя год, 9 декабря 1395 г., республика, прежде уходившая от обсуждения антитурецкого альянса, наконец дала внят- 
ный ответ: она отказалась от вступления в союз под предлогом того, что считала такой шаг малоэффективным из-за отсутствия у нее сухопутных войск; сохранение же нейтралитета должно было позволить ей беспрепятственно направлять в византийскую столицу корабли с продовольствием, в чем были так заинтересованы и сами греки [29, № 892].

Не рассчитывая более на военный союз с Венецией, Византия продолжала уповать на ее экономическую и финансовую поддержку. Республика действительно снабжала осажденный город зерном, о чем свидетельствуют и постановления Сената. Так, по его решению от 9 декабря 1395 г. планировалось направить в Константинополь галеры, груженные от 7 до 8 тыс. стариев пшеницы [29, № 892].

К осени 1395 г. ситуация в столице стала крайне тяжелой, что заставило императора предпринять новые отчаянные шаги. Отсутствие собственных средств и слабая надежда на реальную помощь европейцев побуждали его прибегнуть к нестандартным решениям, а именно к тому, что позднее американский историк Дж. Баркер назовет «реликварной дипломатией (reliquary diplomacy)» [9, p. 408]. В конце осени 1395 г. Мануил Палеолог обратился с просьбой к Венеции о выделении займа, сумма которого нам неизвестна. В качестве же обеспечения кредита он предложил тунику Христа и другие реликвии. Сенат, рассмотрев предложение, ответил крайне уклончиво, пообещав направить своего представителя для обсуждения данного вопроса [29, № 892]. То ли представитель не доехал до Константинополя, то ли переговоры не дали результата, но в начале 1396 г. император через своего посланника вновь обратился к венецианскому Сенату с просьбой о финансовой помощи и напомнил о предложении передать республике в качестве залога тунику Христа и другие реликвии. В инструкции послам Никколо Валарессо и Микеле Контарини, направлявшимся к Баязиду, упоминалось о предложении императора «in pignore dare vestem Yhesu Christi et alias certas reliquias» [12, p. 46-47]. Настойчивость, с которой Мануил Палеолог заявлял о готовности заложить святыни, лучше всяких слов характеризует бедственное положение империи.
Византия в силу своей финансовой несостоятельности, граничившей с банкротством, по сути в завуалированной форме предлагала Венеции выкупить у нее реликвии.

В итоге 15 февраля 1396 г. Сенат принял окончательное решение отказаться от сделки, заявив, что передача реликвий приведет к серьезным беспорядкам в Константинополе, чего не следует допускать [29, № 896; 9, p. 130-131; 7, p. 204]. Ответ, данный республикой торговцев, прежде не слишком радевшей об общественном благополучии византийской столицы, выглядел слишком надуманным, чтобы его можно было принять за чистую монету.

Методы. Греческая исследовательница С. Мергиали-Захас, в своих работах рассматривавшая тему использования в дипломатии Мануила II Палеолога реликвий, выразила удивление по поводу того, что Венеция не соблазнилась заманчивым предложением василевса, но не объяснила мотивы ее отказа, заметив лишь, что за этим мог скрываться прагматизм венецианцев [22, р. 268-269]. Действительно, решение Республики, которая после Четвертого крестового похода не только собрала собственную коллекцию святынь, но и неплохо нажилась на торговле вывезенными из разграбленного Константинополя сокровищами [25, р. 184-185, 410-411], выглядит довольно неожиданным. Ведь каждая такая реликвия могла бы стать для нее хорошим финансовым активом и сулила бы немалые барыши в случае ее перепродажи в отдаленной перспективе. То, что империя не смогла бы ее в дальнейшем выкупить, кажется, ни у кого не вызывало сомнения. В данной статье я попытаюсь выявить причину отказа Венеции от возможности стать обладателем столь значимой святыни. Сопоставление данных византийских и западноевропейских источников и компаративный анализ событий, отражавших характер отношений Византии и Венеции в XIV в., помогут обнаружить истинные мотивы, вынудившие расчетливых венецианцев, никогда не упускавших выгоды, принять столь непростое для них решение.

Анализ. В средневековом христианском мире Константинополь имел славу сокровищницы бесценных реликвий [14]. До Четвертого крестового похода город обладал одной из 


\section{ВИЗАНТИЙСКОЕ ОБЩЕСТВО И ГОСУДАРСТВО}

самых больших коллекций христианских святынь, игравших чрезвычайно важную роль как в религиозной, так и политической жизни имперской столицы. Их использовали в императорских церемониях, военных триумфах, дипломатических сношениях, религиозных практиках как подтверждение величия василевса, христианской церкви и самой империи [21, p. 46-49]. После падения Константинополя многие святыни, будучи одними из самых ценных трофеев латинян, оказались на Западе. Но даже после 1261 г. в городе осталось достаточно реликвий, часть которых, как иронично заметил Дж. Мажеска, странным образом вновь появились в Константинополе [19, c. 390]. К числу почитаемых реликвий, переживших латинское господство и в палеологовское время составлявших сокровища столицы, были одеяния Христа.

Среди реликвий, хранившихся до 1204 г. в церкви Богоматери Фаросской, источники называют две туники: нешвенную тунику (хитон) и багряницу, о которых имеются упоминания в Новом Завете [30, p. 62]. В Евангелиях повествуется о том, как стражники сняли с Христа его одеяние, надели на него багряницу, а затем, насмеявшись над ним, «сняли с него багряницу и одели его в одежды его, и повели его на распятие» (Мк 15:17-20; Мф 27:28-31), а позже «распявшие Его делили одежды его, бросая жребий» (Мк 15:24). Хитон Спасителя, который по жребию делили стражники, согласно евангельскому повествованию, был «не сшитый, а весь тканный сверху» (Ин 19:23).

Не только византийские, но и русские и западноевропейские источники, описывая святыни Фаросской церкви, упоминали тунику Христа и багряницу, в насмешку наброшенную стражниками на плечи Иисуса [8; 19]. Николай Месарит, подробно перечисливший в 1201 г. хранившиеся в церкви реликвии, называет среди них лишь багряницу ( vv íá́tiov) [26, S. 31.3]. В свою очередь, Антоний Новгородец, побывавший в византийской столице около 1200 г., упомянул и багряницу, и «срачицу (сорочку) Господню» [3, c. 19]. Участвовавший в разграблении Константинополя в 1204 г. пикардийский рыцарь Робер де Клари среди реликвий Страстей Господних, составлявших основу коллекции дан- ной церкви, упомянул только тунику, «в которую он был одет и которую с него сняли, когда его вели на гору Голгофу» [2, с. 59]. Часть реликвий Фаросской церкви (терновый венец, гвозди, кровь Христова, часть губки и пр.) были вывезены на Запад, но туника и багряница остались в Константинополе, правда, изменив место хранения. Они вместе с другими уцелевшими реликвиями Страстей Господних сперва находились в монастыре св. Георгия в Манганах, а затем, на рубеже XIV$\mathrm{XV}$ вв., перемещены в монастырь св. Иоанна Продрома в Петре [19, с. 393]. В последнем среди прочих реликвий видели тунику испанские путешественники Руи Гонсалес де Клавихо, проездом посетивший в 1403 г. Константинополь [1, с. 43], и Перо Тафур, побывавший там в 1436 г. [5, с. 172].

В современной научной литературе нет однозначного ответа, была ли предложенная венецианцам туника Христа тем самым нешвенным хитоном Спасителя, входившим в императорскую коллекцию святых реликвий, или речь шла о какой-то другой, о которой нет более ранних упоминаний. Эта неопределенность вызвана противоречивостью данных источников, имеющихся в нашем распоряжении. В императорских документах, подтверждавших аутентичность туники, указано, что реликвия была связана с чудом исцеления женщины, страдавшей от кровотечения (Лк 8:43-48; Мк 5:25-34) [28, № 3256; 12, p. 46-47], но они не называют ее нешвенной. В этих же документах уточняется, что ре-

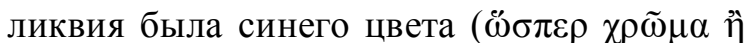
oủpóveov) [11, p. 400], что еще более запутывает ее идентификацию, поскольку о подобной тунике другие источники не упоминают ни до, ни после 1204 г. [22, p. 269-270]. Руи Гонсалес де Клавихо, видевший нешвенную тунику, описал ее как одежду «темно-красного цвета с розовым оттенком» [1, с. 43]. Тафур же упомянул «несшитый хитон нашего Господа, который, как было заметно, некогда был пурпурным, но за долгое время стал каким-то бурым» [5, с. 172]. Дж. Мажеска, говоря о реликвиях византийской столицы, предпочел не обсуждать, какую конкретно «рубашку» Христа видел испанский путешественник, сославшись на сложность ее атрибуции [20, p. 188]. С. Мергиали-Захас, задавшись вопро- 
сом о том, была ли предложенная венецианцам в качестве залога туника идентична нешвенной, высказала предположение, что речь, скорее всего, шла об иной тунике, и это заставило ее усомниться в подлинности «выставленной на торги» реликвии [22, р. 270-271]. Приведенные ею аргументы не выглядят бесспорными, что оставляет данный вопрос до конца неразрешенным. Но каково бы ни было происхождение данной святыни, она была достаточно ценной, чтобы стать предметом дипломатических переговоров.

Именно Мануил II Палеолог положил начало беспрецедентной практике активного привлечения реликвий для решения острых внешнеполитических задач [22, р. 268]. Ранние Палеологи (и Михаил VIII, и Андроник II) не использовали реликвии в дипломатических делах, да и в церемониальной жизни эти святыни, в отличие от более раннего времени, не играли сколько-нибудь заметной роли. Однако по мере истощения материальных ресурсов империи, резко сократившихся в середине XIV в., в реликвиях вновь увидели средство дипломатии и, более того, финансовый инструмент.

Внешнеполитические проблемы и финансовая несостоятельность Византии, которая в условиях осады достигла критического уровня, вынудили Мануила Палеолога обратиться к «неприкосновенному запасу» - реликвиям, являвшимся, по выражению Дж. Шепарда, последними «ценными бумагами» империи [30, p. 63]. Мануил Палеолог использовал реликвии не только как дипломатические подношения, но и предлагал их в качестве залога или платы за присланную или обещанную военную и финансовую помощь. Так, в 1397 г. в благодарность за полученную с Руси милостыню, собранную великим князем Василием I Дмитриевичем и русскими князьями, которая, по сообщениям летописей, составляла 20 тыс. руб. серебром, Мануил Палеолог вместе с патриархом отправил в Москву святые мощи и иконы. Среди даров особенно выделялась «икона чудна», преподнесенная великому князю. Софийская вторая летопись сообщает об этом следующее: «Царь Турскій Баязь, Амуратовъ сынъ, пришедъ оступи Царьградъ со многии силами, и по морю и по суху, и стоя 7 лћть ${ }^{2}$, но не взя его; а прочая грады Гре- ческія попльни. Тогда же князь великій Дмитрей Ивановичь ${ }^{3}$ и сь братьею послаша во Царьградъ много милостыни, оскудњнія ихъ ради...; царь же и патриіархъ благодариша ихъ повелику, и прислаша къ великому князю икону чудну, на нейже есть написанъ Спасъ въ ризицћ бълой; стоитъ же та икона во церкви его Благов на лћвой сторонћ на поклонной» [4, с. 130].

Однако началом этой «реликварной дипломатии» стало предложение в 1395 г. туники Христа венецианцам. Соблазн принять это предложение императора и выделить займ под залог христианских святынь, вероятно, был для венецианцев велик, раз им потребовалось два месяца для принятия окончательного решения. Тем не менее Сенат, как мы видели, ответил отказом. Причина же, по которой он отклонил сделку, состояла, на мой взгляд, в плохой «кредитной истории» Византийской империи - за ней числился полувековой долг, который так и не был покрыт и о котором венецианцы не забывали ни на минуту.

Речь идет о займе в 30 тыс. золотых дукатов, который 21 августа 1343 г. венецианский Сенат выделил Анне Савойской, регентше при малолетнем сыне Иоанне V Палеологе, остро нуждавшейся в деньгах в условиях гражданской войны с Иоанном Кантакузином [28, № 2891]. В качестве залога вдовствующая императрица передала Республике драгоценности императорской короны (если и не все, то, вероятно, большую их часть) [9, p. 443]. Эти драгоценности находились в залоге у венецианцев до тех пор, пока византийское правительство не погасит первоначальный займ вместе с набежавшими процентами. И хотя исходные условия предоставления займа предполагали, что Венеция сможет распоряжаться залогом, если долг не будет выплачен в течение трех лет [29, № $153 ; 28$, № 2891], по факту закладные предметы так и оставались неприкосновенными, поскольку договор постоянно продлевался.

Что скрывалось под столь общей формулировкой как «драгоценности империи»? В греческих источниках предметы, переданные в качестве залога, обозначены как «рега-

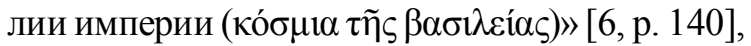
в латинских же - как «драгоценности империи (jocalia imperii)» [9, p. 443]. По мнению 


\section{ВИЗАНТИЙСКОЕ ОБЩЕСТВО И ГОСУДАРСТВО}

Т. Бертеле, это были драгоценности, которые украшали императорскую корону (ं $\sigma \tau \varepsilon \dot{\mu} \mu \alpha)$, используемую в инаугурационных ритуалах [10, p. 157-169]. О том, что императорские инсигнии после 1343 г. отсутствовали в империи, свидетельствует ряд фактов. Согласно сообщению Иоанна Кантакузина, для его коронации в Адрианополе 21 мая 1346 г. ювелиром была специально «изготовлена стемма и другие вещи, необходимые для обряда» $[16$, p. 564]. Во время его повторной коронации уже в Константинополе в 1347 г., как сообщает Никифор Григора, драгоценные украшения в диадемах его и императрицы были в действительности сделаны из стекла [23, p. 788-789], что еще раз подтверждает идентификацию находившихся в залоге у Венеции «регалий империи» с драгоценностями, прежде украшавшими царскую стемму.

О возврате долга и выкупе коронационных драгоценностей венецианцы неоднократно напоминали Византии. При каждом продлении мирного договора, что происходило с периодичностью примерно раз в пять лет, в нем появлялась строчка о необходимости заплатить по счетам и выкупить драгоценности. В договорах начиная с 1357 и вплоть до 1450 г. ${ }^{4}$ неизменно подтверждалось обязательство Византии погасить долг перед Республикой. За 110 лет набежали солидные проценты, которые к 1453 г. составили 165 тыс. дукатов: таким образом, общий долг за драгоценности короны составлял 195 тыс. дукатов [10, p. 135; 25, p. 410]. Видя неспособность империи расплатиться по своим долгам, Венеция на протяжении второй половины XIV в. неоднократно пыталась использовать ее существующие финансовые обязательства для решения текущих политических проблем. Так, желая обладать стратегически важным о. Тенедос, лежавшим у входа в Дарданеллы, венецианцы пытались выторговать его у Византии. В 1362 г. они предложили Иоанну V Палеологу (1341-1391) обменять на этот остров драгоценности короны и еще 20 тыс. дукатов наличными сверху [29, № 355, 358]. В 1370 г. Венеции даже удалось убедить императора подписать договор об уступке Тенедоса в обмен на 25 тыс. дукатов, шесть галер и заложенные его матерью драгоценности [18, p. 221-222], однако сделка сорвалась. В ито- ге коронационные драгоценности так и остались в сокровищнице собора Св. Марка вплоть до конца империи [9, p. 443].

Эта давняя история непогашенного долга удерживала венецианцев от заключения новой сделки, сулившей стать столь же безнадежной. Усугубляло ситуацию и то, что залоговыми вещами Республика, связанная договором, заключенным при оформлении займа, не могла распоряжаться по своему усмотрению. Эти обстоятельства, на мой взгляд, и стали настоящей причиной отказа Венеции от столь, казалось бы, выгодной сделки. Холодный расчет и прагматизм венецианцев одержали верх и уберегли их от принятия сомнительного с точки зрения финансовой выгоды предложения.

История же туники Христа, от которой отказались венецианцы, на этом не закончилась. Ее продолжали использовать как средство достижения внешнеполитических целей, по сути торгуя ею в «розницу». Отправляясь в свою знаменитую поездку на Запад, Мануил Палеолог прихватил с собой различные реликвии, в том числе и эту драгоценную вещь [24, p. 210; 9, p. 162]. В период своего путешествия он щедро одаривал своих потенциальных союзников частицами туники Спасителя. Один ее фрагмент император отправил римскому папе Бонифацию IX (1389-1404), документально (litterae patentes (imperiales)) подтвердив аутентичность реликвии (июль 1401 г.) [11, p. 402-403]. Еще один фрагмент был подарен королеве Маргарите Датской (1387-1412); документ, свидетельствующий об его аутентичности, также прилагался (ноябрь 1402 г.) [11, p. 398-401]. В обоих документах реликвия названа как «частица святой туники самого искупителя нашего Иисуса Христа» ${ }^{5}$. Подобный фрагмент туники был отправлен через византийского посланника Алексея Врану авиньонскому папе Бенедикту XIII (июнь или июль 1400 г.) [28, № 3285]. Преподнесена была часть реликвии и английскому королю Генриху IV (1399-1413) во время пребывания императора в резиденции Элтем в период рождественских торжеств [22, p. 271, note 47]. Такой же дар достался и истовому собирателю христианских святынь арагонскому королю Мартину I (13961410), который в обмен обещал отправить шесть галер в Константинополь [22, р. 273]. 
Спустя годы после завершения первой осады столицы и вскоре после неудачного штурма города османами летом 1421 г. малую частицу реликвии получил фламандский рыцарь и дипломат Жильбер де Ланнуа, побывавший в Константинополе по поручению английского короля Генриха V (1413-1422) и бургундского герцога Филиппа III Доброго (1419-1467). Престарелый Мануил II Палеолог даровал ему ставротеку, в которую были помещены фрагменты «от одежды нашего Господа (de la robe Nostre Seigneur Irrisoria), от плащаницы нашего Господа, от рубахи Богоматери, от мощей святого Стефана и святого Феодора, на каждой части по-гречески написано имя каждой реликвии» [27, p. 65]. Таким образом, туника Христа, все еще находившаяся в столице, продолжала «работать» в качестве ценного дипломатический дара.

Совершенно неожиданно некая «туника Христа» появится в Венеции уже после падения империи: в 1457 г. неизвестный грек предложит Республике купить ее за 10 тыс. дукатов. В этот раз Сенат не будет тянуть с ответом и быстро примет положительное решение [17, p. 103, № 1].

Результаты. Рассмотренный сюжет из поздневизантийской дипломатической практики наглядно иллюстрирует состояние империи, оказавшейся в критической внешнеполитической ситуации. В условиях османской осады столицы и при отсутствии военных и финансовых ресурсов византийский император Мануил II Палеолог был вынужден прибегнуть к крайней мере, пустив в «дипломатический оборот» ту единственную ценность, которой еще располагал и которую можно было конвертировать на христианском Западе. Реликвии, эти свидетельства прежнего величия империи и «мистики византийского прошлого» [22, p. 275], стали предметом дипломатического торга. Происхождение святынь из императорской сокровищницы было достаточным основанием для того, чтобы получатели не испытывали сомнений в их подлинности. Особая роль в подобной дипломатии Мануила Палеолога оказалась отведена тунике Христа, которую император столь настойчиво пытался обменять на деньги и союзническую помощь. Именно ее предложили венецианцам в обеспечение займа, в котором осажденная империя катастрофически нуждалась. Однако прагматичные венецианцы, отказавшись, хотя и не без раздумий, принять ее в качестве залога, ясно дали понять, что не намерены кредитовать империю, финансовое состояние которой было близко к банкротству. Высказанное нами предположение о том, что возможной причиной (или одной из причин) отказа послужил непогашенный Византией займ полувековой давности, кажется вполне убедительным, поскольку тема возврата средств, полученных под залог драгоценностей царской короны, не уходила с повестки дипломатических переговоров между Византией и Венецией до самого конца империи.

Неудача, постигшая императора на переговорах с Венецией, вынудила его еще активнее искать внешнюю поддержку, для чего, в частности, и было предпринято беспрецедентное путешествие Мануила Палеолога по европейским дворам, в которое тот отправился, прихватив с собой святые реликвии. Раздача реликвий в обмен на реальную поддержку или лишь словесные обещания была криком о помощи и мольбой о спасении империи, боровшейся за выживание. Туника Христа, которую император во время поездки щедро раздавал по частям своим потенциальным союзникам, стала зримым выражением «надежды ненадеющихся» ${ }^{6}$, а «реликварная дипломатия», к которой вынужден был прибегнуть Мануил II Палеолог, - его последним отчаянным шагом спасти империю и заинтересовать Запад в ее судьбе.

\section{ПРИМЕЧАНИЯ}

1 Об осаде Константинополя подробнее см.: [9, p. 123-199; 15].

${ }^{2}$ Осада длилась более 8 лет.

3 Ошибка летописца.

${ }^{4}$ Договоры 1357, 1390, 1406, 1418, 1423, 1431, $1442,1447 / 1448$ гг. в греческой версии [6, р. 125, 140, $149,158,168,191,212,220]$ и договоры 1362, 1363, $1370,1390,1406,1418,1423,1431,1442,1450$ гг. в латинской версии [13, p. 85, 90, 154, 227, 301, 317, 341, $346,372,380]$.

5 В латинском варианте документа реликвия названа: «parvam particulam sancte tunice ipsius Redemptoris nostri Jhesu Christi», в греческом:

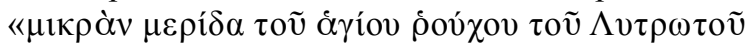

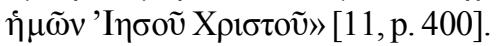


6 Такая надпись была помещена на икону Богоматери Агиосоритиссы, которую Мануил II Палеолог захватил в поездку на Запад. Он подарил ее герцогу миланскому Джан-Галлеаццо Висконти, а в середине XV в. икона оказалась во Фрайзинге, где ныне и хранится [31, p. 266].

\section{СПИСОК ЛИТЕРАТУРЫ}

1. Клавихо, Руи Гонсалес де. Дневник путешествия в Самарканд ко двору Тимура (1403-1406) / Руи Гонсалес де Клавихо ; пер. со староисп., предисл. и коммент. И. М. Мироковой. - М. : Наука, 1990. $-211 \mathrm{c}$.

2. Клари де, Р. Завоевание Константинополя / Р. Клари де. - М. : Наука, 1986. - 175 с.

3. Книга Паломник : Сказание мест святых во Цареграде Антония, архиепископа Новгородского в 1200 г. / под ред. Х. М. Лопарева // Православный палестинский сборник. - 1899. - Вып. 51. - С. 1-111.

4. Софийская вторая летопись // Полное собрание русских летописей. Т. 6. - СПб. : Тип. Эдуарда Праца, 1853. -С. 119-276.

5. Тафур, П. Странствия и путешествия / П. Тафур ; предисл. и коммент. Л. К. Масиеля Санчеса. - М. : Индрик, 2006. - 296 с.

6. Acta et diplomata graeca medii aevi sacra et profana. Vol. 3 / ed. Fr. Miklosich, I. Müller. Vindobonae : Carolus Gerold, 1865. - 393 p.

7. Andriopoulou, St. Diplomatic Communication between Byzantium and the West under the Late Palaiologoi(1354-1453): PhDThesis/St. Andriopoulou. Birmingham, 2010. $-433 \mathrm{p}$.

8. Bacci, M. Relics of the Pharos Chapel : A View from the Latin West / M. Вассі // Восточнохристианские реликвии / ред.-сост. А. М. Лидов. - М. : Прогресс-Традиция, 2003. - С. 234-248.

9. Barker, J. W. Manuel II Palaeologus (13911425) : A Study in Late Byzantine Statesmanship / J. W. Barker. - New Brunswick ; New Jersey : Rutgers University Press, 1969. - 614 p.

10. Bertelè, T. I gioielli della corona bizantina dati in pegno alla Republica veneta nel sec. XIV e Mastino II della Scala / T. Bertelè // Studi in onore di Amintore Fanfani. Vol. 2 : Medioevo. - Milan :A. Guiffrè, 1962.P. 90-177.

11. Dennis, G. Two Unknown Documents of Manuel Palaeologus / G. Dennis // Travaux et mémoires. - 1968. Vol. 3. - P. 397-404.

12. Dennis, G. Official Documents of Manuel II Palaeologus / G. Dennis // Byzantion. - 1971. - T. 41.P. $45-58$.

13. Diplomatarium Veneto-Levantinum, sive Acta et Diplomata res Venetas, Graecas atque Levantis illustrantia. Pars 2, a. 1351-1454 / ed. C. M. Thomas,
R. Predelli. - Venetiis : Sumptibus Societatis, 1899.$451 \mathrm{p}$.

14. Ebersolt, J. Les sanctuaries de Byzance / J. Ebersolt.-Paris : Editions Ernest Leroux, 1921.-159 p.

15. Hatzopoulos, D. Le premier siège de Constantinople par les Ottomans (1394-1402) / D. Hatzopoulos. - Montréal : [s. n.], 1995. - 168 p.

16. Ioannis Cantacuzeni eximperatoris Historiarum libri IV. Vol. 2 / ed. L. Schopen, E. Bekker. - Bonnae : Impensis Ed. Weberi, 1831. -615 p.

17. Jorga, N. Notes et extraits pur servir à l'histoire des Croisades au XV-e siècle. IV. Documents politique / N. Jorga // Revue de l'Orient Latin. T. 8. - Paris : Ernest Leroux Editeur, 1900-1901.- P. 1-115.

18. Loenertz, R.-J. Jean V Paléologue à Venise (1370-1371) / R.-J. Loenertz // Revue des études byzantines. -1958 . - T. 16. - P. 217-232.

19. Majeska, G. Russian Pilgrims and the Relics of Constantinople / G. Majeska // Восточнохристианские реликвии / ред.-сост. А. М. Лидов. - М. : Прогресс-Традиция, 2003. - С. 387-397.

20. Majeska, G. P. The Relics of Constantinople After 1204 / G. P. Majeska // Byzance et les reliques du Christ / ed. J. Durand, B. Flusin. - Paris : Centre de recherche d'histoire et civilisation de Byzance, 2004. P. 183-190.

21. Mergiali-Sahas, S. Byzantine Emperors and Holy Relics. Use, and Misuse of Sanctity and Authority / S. Mergiali-Sahas // Jahrbuch der österreichischen Byzantinistik. - 2001. - Bd. 51. - P. 41-60.

22. Mergiali-Sahas, S. An Ultimate Wealth for Inauspicious Times: Holy Relics in Rescue of Manuel II Palaeologus' Reign / S. Mergiali-Sahas // Byzantion. - 2006. - T. 86. - P. 264-275.

23. Nicephori Gregorae Byzantina historia. Vol. 2 / ed. L. Schopen, I. Bekker. - Bonn : Impensis Ed. Weberi, 1830. -1385 p.

24. Nicol, D. A Byzantine Emperor in England : Manuel II's Visit to London in 1400-1401 / D. Nicol // University of Birmingham Historical Journal. 1970. - Vol. 12. - P. 204-225.

25. Nicol, D. Byzantium and Venice : A Study in Diplomatic and Cultural Relations / D. Nicol. Cambridge : Cambridge University Press, 1988. - 425 p. 26. Nikolaos Mesarites. Die Palastrevolution des Johannes Komnenos / ed. A. Heisenberg. - Würzburg : K. Universitäts-Druckerei von H. Stürtz, 1907. - 77 p. 27. Oeuvres de Ghillebert de Lannoy, voyageur, diplomate et moraliste / rec. et. publ. par Ch. Potvin.Louvain : Impr. de P. et J. Lefever, 1878. - 551 p.

28. Regesten der Kaiserurkunden des oströmischen Reiches von 565-1453. Bd. 5 / bearb. von F. Dölger. München; Berlin : Verlag C. H. Beck, 1965. - 138 S.

29. Régestes des délibérations du Sénat de Venise concernant la Romanie. Vol. 1 / éd. par F. Thiriet. Paris ; La Haye : Mouton, 1958. - 247 p. 
30. Shepard, J. Imperial Constantinople : Relics, Palaiologan Emperors, and the Resilience of the Exemplary Centre / J. Shepard // Byzantines, Latins, and Turks in the Eastern Mediterranean World after 1150 / ed. J. Harris, C. Holmes, E. Russell. - Oxford : Oxford University Press, 2012. - P. 61-92.

31. Vassilaki, M. Praying for the Salvation of the Empire? / M. Vassilaki // Images of the Mother of God. Perceptions of the Theotokos in Byzantium / ed. M. Vassilaki. - Ashgate : Routledge, 2005. P. 263-276.

\section{REFERENCES}

1. Klavikho R.G. de. Dnevnik puteshestviya v Samarkand ko dvoru Timura (1403-1406) [Diary of a Journey to Samarkand to the Court of Timur (14031406)]. Moscow, Nauka Publ., 1986. 211 p.

2. Klari R. de. Zavoevanie Konstantinopolya [Conquest of Constantinople]. Moscow, Nauka Publ., $1986.175 \mathrm{p}$.

3. Loparev Kh.M., ed. Kniga Palomnik: Skazanie mest svyatykh vo Tsaregrade Antoniya, arkhiepiskopa Novgorodskogo v $1200 \mathrm{~g}$. [Book of the Pilgrim: The Legend of the Places of the Saints in Tsargrad by Anthony, Archbishop of Novgorod in 1200]. Pravoslavnyy palestinskiy sbornik, 1899, iss. 51, pp. 1-111.

4. Sofiyskaya vtoraya letopis [The Sofia Second Chronicle]. Polnoe sobranie russkikh letopisey [The Complete Collection of Russian Chronicles]. Saint Petersburg, Tipografiya Eduarda Pratsa, 1853, pp. 119-276.

5. Tafur P. Stranstviya $i$ puteshestviya [Wanderings and Journeys]. Moscow, Indrik Publ., 2006. 296 p.

6. Miklosich Fr., Müller I., eds. Acta et diplomata graeca medii aevi sacra et profana. Vol. 3. Vindobonae, Carolus Gerold, 1865.393 p.

7. Andriopoulou St. Diplomatic Communication Between Byzantium and the West Under the Late Palaiologoi (1354-1453): PhD Thesis. Birmingham, s.n., $2010.433 \mathrm{p}$

8. Bacci M. Relics of the Pharos Chapel: A View from the Latin West. Lidov A. M., ed. Vostochnokhristianskie relikvii [Eastern Christian Relics]. Moscow, Progress-Traditsiya Publ., 2003, pp. 234-248.

9. Barker J.W. Manuel II Palaeologus (13911425): A Study in Late Byzantine Statesmanship. New Brunswick, New Jersey, Rutgers University Press, 1969. $614 \mathrm{p}$.

10. Bertelè T. I gioielli della corona bizantina dati in pegno alla Republica veneta nel sec. XIV e Mastino II della Scala. Studi in onore di Amintore Fanfani. Vol. 2: Medioevo. Milan, A. Guiffrè, 1962, pp. 90-177.
11. Dennis G. Two Unknown Documents of Manuel Palaeologus. Travaux et mémoires, 1968, vol. 3, pp. 397-404.

12. Dennis G. Official Documents of Manuel II Palaeologus. Byzantion, 1971, vol. 41, pp. 45-58.

13. Thomas C. M., Predelli R., eds. Diplomatarium Veneto-Levantinum, sive Acta et Diplomata res Venetas, Graecas atque Levantis illustrantia. Pars 2, a. 1351-1454. Venetiis, Sumptibus Societatis, 1899. 451 p.

14. Ebersolt J. Les sanctuaries de Byzance. Paris, Editions Ernest Leroux, 1921. 159 p.

15. Hatzopoulos D. Le premier siège de Constantinople par les Ottomans (1394-1402). Montréal, s.n., 1995. 168 p.

16. Schopen L., Bekker E., eds. Ioannis Cantacuzeni eximperatoris Historiarum libri IV. Vol. 2. Bonnae, Impensis Ed. Weberi, 1831.615 p.

17. Jorga N. Notes et extraits pur servir à l'histoire des Croisades au XV-e siècle. IV. Documents politique. Revue de l'Orient Latin. T. 8. Paris, Ernest Leroux Editeur, 1900-1901, pp. 1-115.

18. Loenertz R.-J. Jean V Paléologue à Venise (1370-1371). Revue des études byzantines, 1958, vol. 16, pp. 217-232.

19. Majeska G. Russian Pilgrims and the Relics of Constantinople. Lidov A. M., ed. Vostochnokhristianskie relikvii [Eastern Christian Relics]. Moscow, ProgressTraditsiya Publ., 2003, pp. 387-397.

20. Majeska G.P. The Relics of Constantinople After 1204. Durand J., Flusin B., eds. Byzance et les reliques du Christ. Paris, Centre de recherche d'histoire et civilisation de Byzance, 2004, pp. 183-190.

21. Mergiali-Sahas S. Byzantine Emperors and Holy Relics. Use, and Misuse of Sanctity and Authority. Jahrbuch der österreichischen Byzantinistik, 2001, Bd. 51, S. 41-60.

22. Mergiali-Sahas S. An Ultimate Wealth for Inauspicious Times: Holy Relics in Rescue of Manuel II Palaeologus' Reign. Byzantion, 2006, vol. 86, pp. 264-275.

23. Schopen L., Bekker E., eds. Nicephori Gregorae Byzantina historia. Vol. 2. Bonn, Impensis Ed. Weberi, 1830. 1385 p.

24. Nicol D. A Byzantine Emperor in England: Manuel II's Visit to London in 1400-1401. University of Birmingham Historical Journal, 1970, vol. 12, pp. 204-225.

25. Nicol D. Byzantium and Venice: A Study in Diplomatic and Cultural Relations. Cambridge, Cambridge University Press, 1988. 425 p.

26. Heisenberg A., ed. Nikolaos Mesarites. Die Palastrevolution des Johannes Komnenos. Würzburg, K. Universitäts-Druckerei von H. Stürtz, 1907. 77 p.

27. Potvin Ch., ed. Oeuvres de Ghillebert de Lannoy, voyageur, diplomate et moraliste. Louvain, Impr. de P. et J. Lefever, 1878. 551 p. 


\section{ВИЗАНТИЙСКОЕ ОБЩЕСТВО И ГОСУДАРСТВО}

28. Dölger F., ed. Regesten der Kaiserurkunden des oströmischen Reiches von 565-1453. Bd. 5. München, Berlin, Verlag C.H. Beck, 1965. 138 S.

29. Thiriet F., ed. Régestes des délibérations $d u$ Sénat de Venise concernant la Romanie. Vol. 1. Paris, La Haye, Mouton, 1958. 247 p.

30. Shepard J. Imperial Constantinople: Relics, Palaiologan Emperors, and the Resilience of the
Exemplary Centre. Harris J., Holmes C., Russell E., eds. Byzantines, Latins, and Turks in the Eastern Mediterranean World After 1150. Oxford, Oxford University Press, 2012, pp. 61-92.

31. Vassilaki M. Praying for the Salvation of the Empire? Vassilaki M., ed. Images of the Mother of God. Perceptions of the Theotokos in Byzantium. Ashgate, Routledge, 2005, pp. 263-276.

\section{Information About the Author}

Tatiana V. Kushch, Doctor of Sciences (History), Associate Professor, Head of the Department of Ancient and Medieval History, Ural Federal University, Prosp. Lenina, 51, 620000 Yekaterinburg, Russian Federation; Chief Researcher, Institute of World History of the Russian Academy of Sciences, Prosp. Leninsky, 32a, 119334 Moscow, Russian Federation, tkushch@yandex.ru, https://orcid.org/0000-0001-9097-5466

\section{Информация об авторе}

Татьяна Викторовна Кущ, доктор исторических наук, доцент, заведующая кафедрой истории Древнего мира и Средних веков, Уральский федеральный университет, просп. Ленина, 51, 620000 г. Екатеринбург, Российская Федерация; главный научный сотрудник, Институт всеобщей истории РАН, Ленинский просп., 32a, 119334 г. Москва, Российская Федерация, tkushch@yandex.ru, https://orcid.org/0000-0001-9097-5466 